\title{
Development of Integrated River Basin Management for Godavari Basin towards Johannesburg Plan of Sustainable Development
}

${ }^{{ }^{1}}$ Gurusamy B T, ${ }^{2}$ Vasudeo A D, ${ }^{3}$ Gautam N R, ${ }^{4}$ Godbole S P

${ }^{1,2}$ Department of Civil Engineering, VNIT, Nagpur, India

${ }^{3}$ Civil Department, Priyadarshini Bhagwati College of Engineering, Nagpur, India

${ }^{4} \mathrm{Dr}$. Ambedkar Institute of Management Studies and Research, Nagpur, India

Email: 19uru19april2009@gmail.com, ${ }^{2}$ avasudeo@yahoo.com, ${ }^{3}$ nimita_gautam@yahoo.co.in, ${ }^{4}$ snehal_prakash1@rediffmail.com

Received: 06th November 2019, Accepted: 20th November 2019, Published: 31st December 2019

\begin{abstract}
This paper reviews the efforts of United Nations towards the Planning and Implementation of Sustainable Development at all levels of the administration of all nations across the world. The basic concepts of Integrated Water Resources Management (IWRM) and Integrated River Basin Management (IRBM) and its effectiveness to realize sustainable development of a river basin have been explored. Various water related issues that are observed to be present across the Godavari Basin and need to be solved using the Johannesburg Plan of Sustainable Development approaches have been examined. The progress that is being monitored by the Government of India towards the achievement of Sustainability Development Goals (SDGs) across the Godavari Basin of India has been presented. The effectiveness of various approaches such as Water-Energy-Food Nexus and Climate-Resilient Development towards sustainable development of the river basin has been analyzed.
\end{abstract}

\section{Keywords}

Johannesburg Plan of Sustainable Development, IWRM and IRBM Practices, Godavari Basin of India, WaterEnergy-Food Nexus, Climate-Resilient Development

\section{Introduction}

It is the United Nations (UN) with headquarter at New York and had been established after the World War II, as an intergovernmental organization to bear the responsibility for maintaining international peace, security, and being the centre to harmonize the activities of various Countries (UN, 2015). [16] The Concept of Integrated Water Resources Management (IWRM) had been emphasized by United Nations starting from its 1977 UN Water Conference (UN, 1977). [15] United Nations Conference on Environment and Development (UNCED, 1992) [17] was organized in the year 1992 at Rio de Janeiro, Brazil, to address the Problems of Environmental Protection as well as Development of socioeconomic status across the world. The "Agenda 21" was the product of this Earth Summit, where the 21 refers to the 21st century. The aim of Agenda 21 is to achieve global sustainable development. It is such that the criteria of Agenda 21 can be executed at all levels such as local, national and global. The Objective was to consider this Agenda as the main objective of all local governments. For effective follow up of the implementation of Agenda 21, a Commission on Sustainable Development (CSD) was established by December 1992 and was replaced in 2013 by the High-level Political Forum on Sustainable Development. A set of eight Millennium Developments Goals (MDGs) characterizing the Agenda 21, had been proposed by United Nations Millennium summit organized in the year 2000 and planned to get achieved by 2015 (UNDP, 2006). [18] The next International Conference organized by UN is at Johannesburg in the year 2002 which is called as World Summit on Sustainable Development (WSSD). The Outcome of this Summit is the set of Commitments, declarations and guidance for implementation of Sustainable Development at all levels across the world by all nations and collectively called as Johannesburg Plan of Sustainable Development. This became the updated version of Agenda 21 and having a set of guiding Principles including the implementation of Integrated Water Resources Management (IWRM) at all levels across the world (WHO, 2003). [20] United Nations General Assembly had replaced the MDGs by 2015 using a set of Sustainable Development Goals (SDGs) to be achieved by 2030 in the form of Agenda 2030 and also adopted by NITI Aayog of India. This National Institution for Transforming India had been created by replacing the well known Planning Commission of India (NITI, 2018). [12] These SDGs are the Collection of 17 Goals. Accordingly the Planning of India becomes the part of SDGs based Global Planning for Sustainable Development across the world proposed by United Nations.

\section{Materials and Methods}

Integrated Water Resources Management (IWRM) has been defined as a process of coordinated development of Water, Land and Related Resources, to obtain maximum Social and Economic Welfare without compromising the sustainability of Ecosystem (Jounch, 2004). [9] For the efficient implementation of IWRM Criteria to achieve the Sustainability Goals across the World, the Global Water Partnership had developed a IWRM 
Toolbox (GWP, 2003). [7] This Toolbox is acting as a common Platform across the world to share the knowledge and experiences in the implementation of IWRM. This IWRM Toolbox is containing over 50 methods to implement the IWRM approach. This Global Water Partnership had been created by United Nations Development Programme, the World Bank and the Swedish International Development Agency by the year 1996.According to the provisions of National Water Policy, a Basin boundary should be considered as a basic hydrological unit for the analysis towards Water Resources Planning and Management. The necessity of implementing the Integrated Water Resources and Watershed Management Principles by any Water Resources Projects has also been emphasized by the Ministry of Water Resources, Government of India through its National Water Policy (MoWR, 2012). [10] When the Principles of IWRM are applied to the development and Governance of a River basin then it is called as Integrated river Basin Management (IRBM). Accordingly IRBM becomes the subset of IWRM. Total Catchment Management and Integrated Catchment Management are the other terms used to represent the principles if IRBM Balanced, Strategic and Partnership based Systems Approach are being followed by the IRBM. Basin wide Planning, Participation in decision making, Demand Management, etc are some of the elements in IRBM (Hooper, 2005). [8] The Godavari Basin located as shown in Figure 1 has been considered to analyze the effectiveness of IWRM towards Sustainable Development.

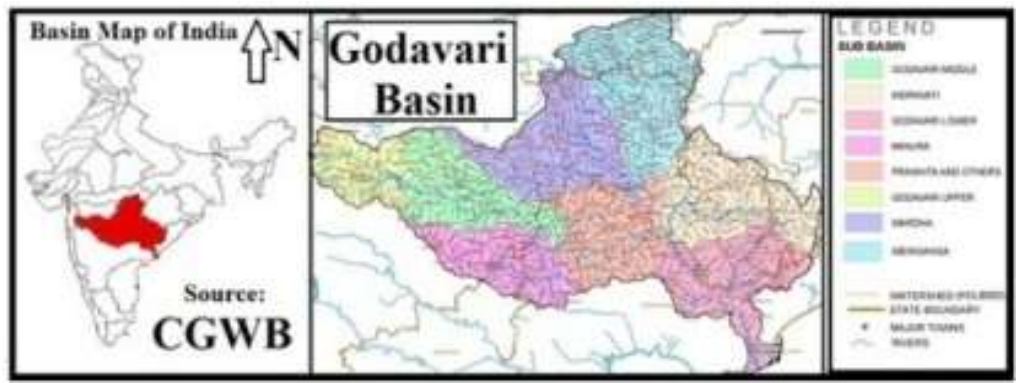

Figure 1: Location of Godavari Basin in India along with its Sub-basins and Watershed Boundaries (CGWB)

According to Henri Fayol, any Management process can be divided into a set of functions including Planning, Organizing, Staffing, Directing and Controlling (Fayol, 1917).[6] Every State of India is having its own Water Resources Department to perform these management functions in the area of its own jurisdiction. The Ministry of Water Resources of India through its organized divisions including CWC, CGWB, NWDA, IMD, NRSC, etc is also performing these management functions across India within the limit of its own pre defined Responsibility and Authority. Various Methods for observing and processing Hydrological data have been standardized by these organizations in the form of Reference Manual which have been prepared in synchronization with that global standard made available through sub-divisional organizations of United Nations including FAO and WMO. A set of Water Resources Databases have been created, regularly updated using observed data and processed information and maintained by Public and Private Organizations both at National and Global levels to keep the data and information available to the Public. The data and information about the Water Resources of Godavari basin are available through CWC, CGWB, IMD, Water Resources Department of Maharashtra, etc. These databases are used by the concerned Water Management Authority to perform above said Management Functions Efficiently.

According to FAO of the UN (FAO, 2014), [5] the Water-Energy-Food Nexus approach tries to characterize the inter-relationship and interdependencies that exist among these three resource demanding sectors for the purpose of balancing the resource allocation across the three sectors and thereby to achieve the SDGs across the Basin. Nexus approach also demands for the Integrated Solutions in order to increase the security of Water, Food and Energy at Global level. Rasul (2015) [13] had presented that the interdependency that exist across these three sectors also influences the policies of other areas such as Climate and Biodiversity and also recommended that Nexus approach can act as an adaptation for Climate Change Impacts. Nexus approach can help to meet the increasing demand without compromising sustainability.

The Climate Resilience of a River basin system has been defined as its capacity to absorb the stress produced by the Climate Change Impacts and hence ability to retain the sustainability of the system. Climate Adaptation is the process of deliberate Change based on the anticipated stress that can be produced because of the Climate Change Impacts. Climate adaptation builds up the Climate Resilience (Nelson, 2007). [11] United States Agency for International Development (USAID) has standardized a framework of Procedures for proper implementation of Climate Resilient Development across the world. According to (USAID, 2014), [19] Climate Resilient Development involves in preserving the development process of a System and minimizing the damages by proper adaptation to future Climate Change Impacts. In the decision making about the development process the parameters about Climate Change Impacts are also need to be considered. Climate Resilient 
Development tries to minimize the cost and consequences of Climate Change Impacts while preserving the progress towards development goals. Accordingly the Climate Resilient Development becomes the component of the Sustainable Development.

\section{Results and Discussions}

The Spatial variation of Annual Average Rainfall, Altitude and drainage network across Godavari Basin had been published by (CWC, 2014) [1] as shown in Figure 2. This Figure shows the existing dislocation of High Rainfall concentration over the low altitude Regions of the Godavari basin and vice versa. This becomes one of the major issues for a Water Resources Manager in his Rational Planning of increasing Water Use Efficiency. Highly seasonal concentrated characteristics of Rainfall and Runoff across the Godavari Basin are shown in Figure 3. This creates a major issue for the Water Resources Manager to search for the Surface as well as Ground Water Storage structures to satisfy the need of uniformly distributed water demand along all the season. As per the principle of IWRM, to balance spatio-temporal variations in the water resources availability, the actual development of Surface Water Gross Storage Capacity across Godavari basin is shown in Figure 4. Even though the observed annual Runoff loss from the basin is about $117 \mathrm{BCM}$ as shown in Table 1, the developed Surface Water Storage Capacity is less than 50 BCM.

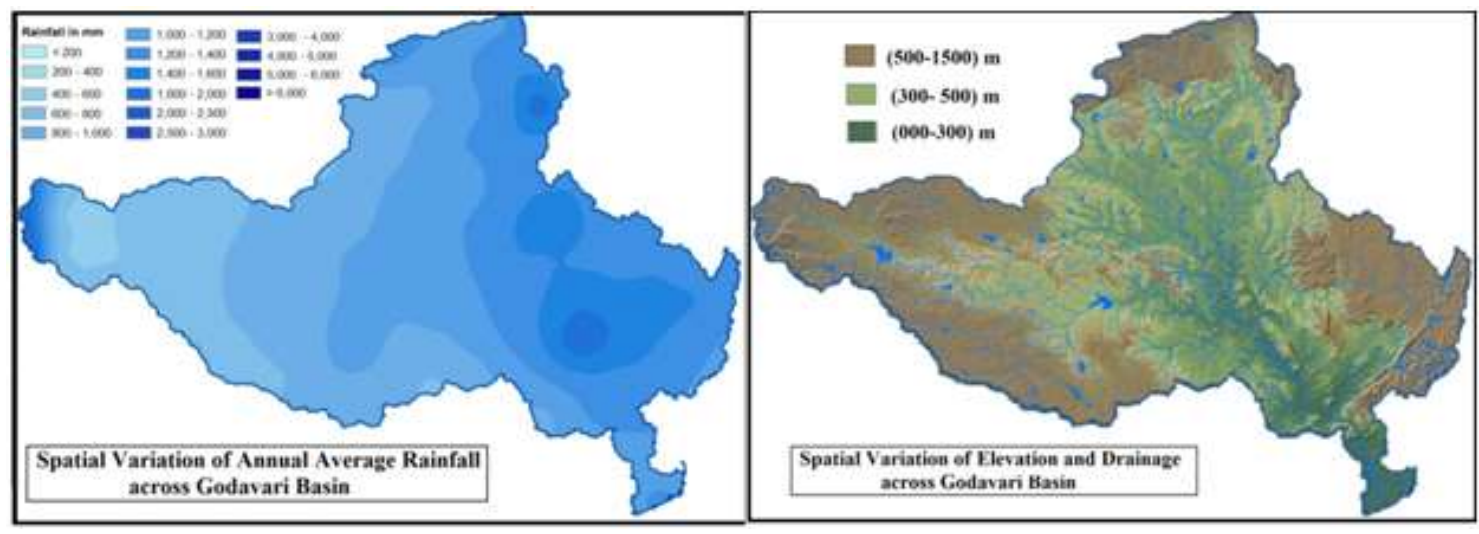

Figure 2: Issues in Dislocation of High Rainfall Concentration over Low Altitude Regions \& Vice Versa (CWC)

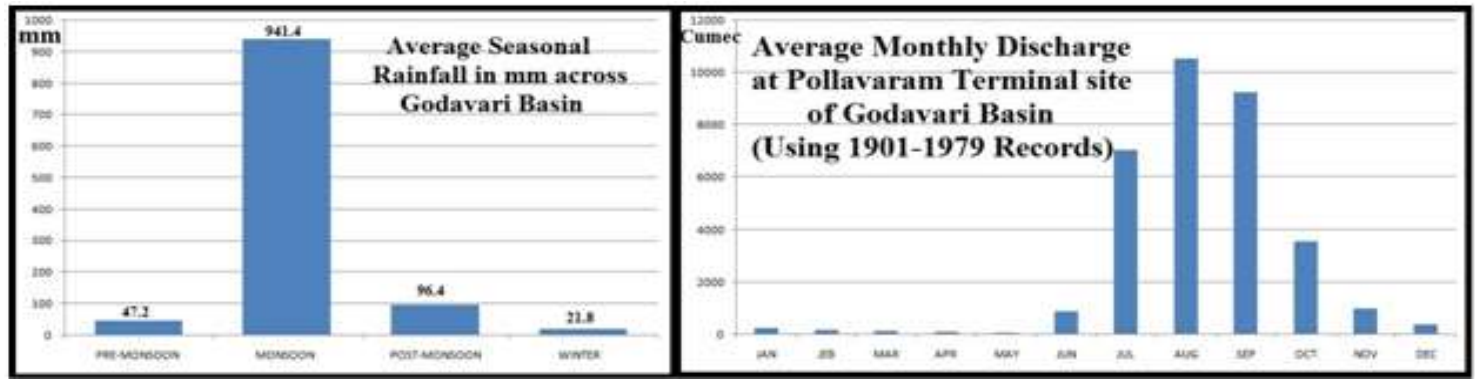

Figure 3: Highly Seasonal Rainfall and Runoff temporal Concentration Issues over Godavari Basin (SAGE)

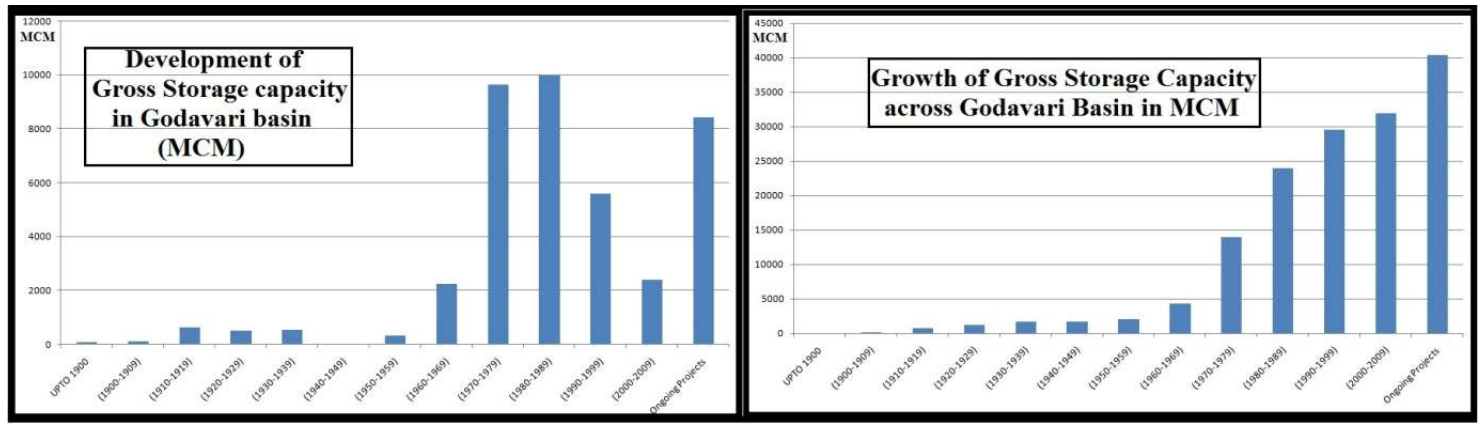

Figure 4: Development of Surface Water Gross Storage Capacity across Godavari Basin (DSO, 2009) 
The percentage area of Godavari basin occupied by different states of India such as Maharashtra, Telangana, Chhattisgarh, Madhya Pradesh, Odisha, Andhra Pradesh and Karnataka are reported to be respectively 48.7\%, $20.1 \%, 12.4 \%, 7.8 \%, 5.7 \%, 3.7 \%$ and $1.4 \%$ (CWC, 2014). [1] This has created another issue of water sharing problem across the States. Godavari Water Disputes Tribunal (GWDT) is a body of Organization constituted by the Government of India to implement the principle of participatory approach of the IRBM, to resolve the Godavari Water sharing problem across the different states.

Annual Water Balance Equation for a Basin used in Table 1 having billion cum (BCM) unit can be written as: (Total Rainfall Inflow=Surface Runoff outflow at Terminal Site+ Groundwater Recharge + Evapotranspiration) The annual water balance of Godavari Basin is compared with that of India as shown in the Table 1. The issues in the form of relatively high Evapotranspiration loss occurring in the Godavari basin are presented in Table 1.

\begin{tabular}{|c|c|c|c|c|}
\hline $\begin{array}{c}\text { Geographical } \\
\text { Region }\end{array}$ & $\begin{array}{c}\text { Rainfall Inflow } \\
(\mathrm{BCM})\end{array}$ & $\begin{array}{c}\text { Runoff Outflow } \\
(\mathrm{BCM})\end{array}$ & $\begin{array}{c}\text { Ground Water Recharge } \\
(\mathrm{BCM})\end{array}$ & $\begin{array}{c}\text { Evapotranspiration } \\
\text { loss (BCM) }\end{array}$ \\
\hline India & $3838(100 \%)$ & $1869(48.7 \%)$ & $432(11.3 \%)$ & $1537(40 \%)$ \\
\hline $\begin{array}{c}\text { Godavari } \\
\text { Basin }\end{array}$ & $365(100 \%)$ & $117(32 \%)$ & $47(12.9 \%)$ & $201(55.1 \%)$ \\
\hline
\end{tabular}

Table 1: Issues in the Relatively High Value of Evapotranspiration Loss over Godavari Basin (CWC, 2017)

It is the Industrial Revolution started from $17^{\text {th }}$ Century which converted the human life system as a Mechanized System involving the huge exploitation of Natural Energy Resources which caused for the injection of $\mathrm{CO}_{2}$ in to the atmosphere. Its consequences became the climate change, to impact the water balance with increased evapotranspiration loss. Hence the principles of Climate Resilient Development as proposed by USAID need to be implemented across any river basins to reduce the impacts by proper Climate Adaptation (ECA, 2009). [4] Performance Index Scores defined, monitored and published by NITI Aayog (2018) [12] as in Figure 5 have been used to compare the achievement of SDGs across Godavari Basin. It is observed that the available Water and Energy Resources are not efficiently used to increase infrastructure and bring down Poverty and hunger level.

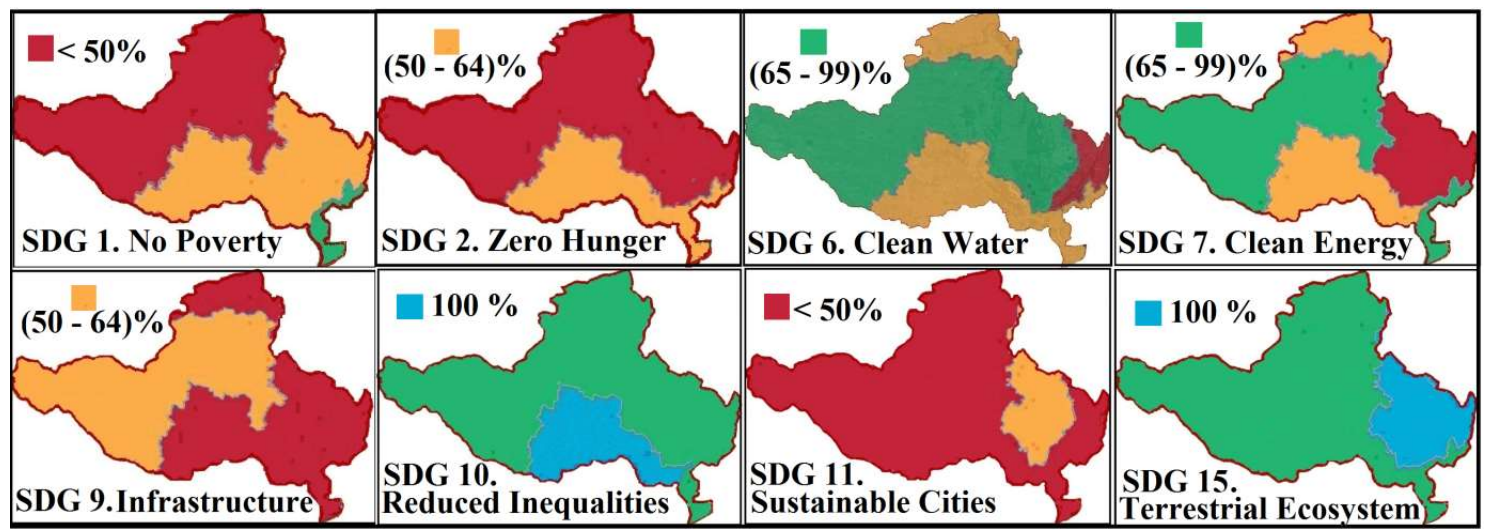

Figure 5: Achievement of UN Agenda 2030 SDGs across Godavari Basin (Source: NITI Aayog, 2018)

\section{Conclusions}

The hub of a fan is in balanced equilibrium by appropriate positioning of the three blades on its circumference. Any inappropriate positioning of the blades will create imbalance and leads to the failure of the system. Accordingly, assuming the river basin as the hub of a fan, and the demand offered by the three sectors as three blades, the basin will be in sustainable equilibrium under appropriate allocation of resources across the three sectors called as Water Sector, Food Sector and Energy Sector because of the interdependency of each of these three sectors. The term Nexus introduced by FAO of the UN is used to define and determine the equilibrium position of the basin by analyzing the complex interrelationship existing among these three sectors. It is a challenge to determine the nexus point of a basin in the form cross-sectored allocation of resources across these three sectors to ensure balanced equilibrium for sustainability. The Water-Energy-Food-Nexus Approach should be included in the planning phase of IWRM to optimize the efficiency of IWRM across a basin. It is the economic development measured in terms of GDP value produced by the output products and services assuming that the loss of system capacity can be compensated by the depreciation accounting process. But the system capacities such as loss of biodiversity, loss of natural fuel resources, etc cannot be compensated by the depreciation accounting process. It is the sustainable development trying to retain or conserve the natural system capacities including the rights of flora, fauna and low income group human communities of the natural 
ecosystem during the development process of producing output GDP and hence the justice level of sustainable development is somewhat higher than that of economic development which has the rational characteristics of optimizing the profit and wealth of a system. Accordingly as mentioned by the FAO of the UN, the sustainable development is a holistic approach that need to followed not only in the domain of water resources management but also across the entire administration process of a country in a way similar to the vision of NITI Aayog of the Government of India. IWRM has been characterized in terms of economic efficiency, social equity by poverty reduction and environmental sustainability. Hence IWRM having IRBM as a subset can be considered as a sustainable solution to any of the water related issues across any river basin.

\section{Acknowledgement}

The research facilities that have been provided by the administration of VNIT Nagpur, UN Information about Global SDGs, the water resources data that have been published by Government of India through its Subordinate organizations such as CWC, NWDA, IMD, CGWB, NRSC and WRIS and Various Services such as Web, Google Earth, Wikipedia \& Search Engines available through internet communications are acknowledged.

\section{References}

[1]CWC and NRSC 2014. Godavari Basin Report Version 2.0. Ministry of Water Resources, Govt of India.

[2]CWC, 2017 Reassessment of Water Availability In India" Central Water Commission, Government of India.

[3]DSO, 2009, Dam Safety Organization of Central Water Commission CWC, "National Register of Large Dams", CWC Publications, India

[4]ECA, 2009, Shaping Climate Resilient Development: a framework for decision making. Economics of Climate Adaptation, Climate Works Foundation, European Commission, McKinsey \& Company.

[5]FAO, "The Water-Energy-Food Nexus A new approach in support of food security and sustainable agriculture" Food and Agriculture Organization of the United Nations Rome, 2014

[6]Fayol, Henri, Paris, H. Dunod et E. Pinat, (1917), "Administration, organization, commandment, coordination and control" OCLC 40224931

[7]GWP, (2003). "Global Water Partnership Toolbox for Integrated Water Resources Management", http://www.gwptoolbox.org/gfx/content/ToolBox\%20text\%20book\%20Ver2\%20Eng.pdf,

[8]Hooper B, (2005) IWA Publishing. "Integrated River Basin Governance: Learning from International Experience" ISBN: 1843390884

[9]Jønch Clausen T. 2004. Integrated Water Resource Management (IWRM) and Water Efficiency Plans by 2005 : Why, What and How?. TAC Background Paper No. 10. Global Water Partnership, Stockholm.

[10]MoWR, "National Water Policy (2012)", Ministry of Water Resources, Government of India.

[11]Nelson D R et al. (2007), "Adaptation to Environmental Change: Contributions of a Resilience Framework", Annual Review of Environment and Resources, 32: 395-419.

[12]NITI Aayog SDG India Index Base Line Report 2018, National Institution for Transforming India, Government of India.

[13]Rasul, Golam (April 2015). "The nexus approach to water-energy-food security: an option for adaptation to climate change". Climate Policy. 16 (6): 682-702. doi:10.1080/14693062.2015.1029865

[14] SAGE, 2005, Center for Sustainability and the Global Environment, "River Discharge Database", Gaylord Nelson Institute for Environmental Studies, University of Wisconsin-Madison.

[15]UN, 1977: Report of the United Nations Water Conference, Mar del Plata, 14-25 March 1977, E/CONF.70/29. New York, United Nations.

[16]UN Charter, Chapter I - Article 1-2, 2015, https://www.un.org/en/sections/un-charter/chapter-i/index.html

[17]UNCED, "United Nations Sustainable Development Agenda 21", United Nations Conference on Environment \& Development, Rio de Janerio, Brazil, 3 to 14 June 1992

[18]UNDP. 2006. Millennium Development Goals - MDGs. http://www.undp.org/mdg/basics.shtml

[19]USAID, 2014 "Climate-Resilient Development: A Framework for Understanding and Addressing Climate Change", United States Agency for International Development, Global Climate Change Office, Washington, DC [20]WHO, "World Summit on Sustainable Development: Key Outcomes, Challenges and Opportunities for Health and Sustainable Development. World Health Organization 2003 